\title{
IMPLICATIONS OF A CONSTRUCTION FOR THE THEORY OF GRAMMATICALIZATION: ESTONIAN ADESSIVE MANNER AND CAUSE ADVERBIALS
}

\author{
Heete Sahkai
}

Institute of the Estonian Language, Tallinn

\begin{abstract}
The paper proceeds from a comparison of a grammaticalization and a constructional account of a class of formulaic adverbial expressions from Estonian. The comparison is argued to reveal that the grammaticalization analysis is informed by a particular synchronic model of grammar, and thus that the study of grammaticalization more generally is dependent on the assumed conception of grammar. The paper then goes on to discuss some implications of basing the study of grammaticalization on a constructional model of language, and sketches a constructional view of some diachronic aspects of the expressions under study. It will be concluded that the constructional model provides a useful basis for the study of grammaticalization.
\end{abstract}

DOI: $10.3176 /$ tr.2009.4.04

Keywords: nominalizations, adessive, construction grammar, grammaticalization, Estonian

\section{Introduction}

The aim of this paper is to argue that the study of grammaticalization is dependent on the assumed conception of grammar, and to discuss some implications of basing the study of grammaticalization on a constructional model of language. The paper will examine two accounts of a class of formulaic adverbial expressions from Estonian: an account in terms of grammaticalization and a constructional account. On the former approach, the expressions are hypothesized to result from an ongoing grammaticalization of noun forms into postpositions. On the constructional approach, they could be analyzed as licensed by a stable construction or 'formal idiom', i.e. an idiosyncratic partially productive morphosyntactic pattern, represented independently of the lexical items that occur in it, and associated with meaning. The comparison of the two analyzes will be argued to reveal that the grammaticalization account presupposes a particular conception of grammar. More generally, it will be maintained that the conception of grammaticalization is 
informed by particular synchronic assumptions about grammar, and that the constructional model of grammar would give rise to a somewhat different conception of grammaticalization - one which, it will be argued, conforms well with the findings of grammaticalization studies.

The paper is structured as follows. Section 2 will describe the expressions under study. Section 3 will discuss the problems of the grammaticalization account of these expressions and section 4 will propose a constructional analysis. Section 5 will argue that the grammaticalization analysis of the expressions and the conception of grammaticalization more generally are informed by particular synchronic assumptions about grammar which however can be seen to conflict with the findings of grammaticalization studies. Section 6 will consider the possibilities of describing linguistic change in terms of constructions and discuss the implications of adopting the constructional model as the model of grammar underlying the study of grammaticalization. Section 7 will present the conclusions.

\section{Adessive manner and cause expressions}

The paper is based on the case study of a class of Estonian adverbial expressions displaying a range of syntactic and semantic properties that are not predicted by the categorial, combinatorial and semantic properties of their heads and therefore present a problem for a conception of grammar which assumes complex expressions to be projections of the combinatorial properties of their component elements and to have compositional meaning (a more detailed description of the expressions is given in Sahkai 2006). The expressions function as manner or cause (or occasionally condition) adverbials and consist of the adessive case form of an action nominalization, a genitive attribute realizing the actor argument of the nominalization, and optional adjectival modifiers ${ }^{1}$ :

$\begin{array}{llll}\text { (1) Hanza.net } & \text { uueneb } & \text { klientide } & \text { soovil } \\ \text { Hanza.net } & \text { renew-PRS.3SG } & \text { client-PL-GEN } & \text { wish-SG-ADESS }\end{array}$

'Hanza.net is being updated at the wish of their clients'

(www.parnupostimees.ee/130604/esileht/uudised/10048301.php)

(2) Punase Risti töötajate aktiivsel

red-SG-GEN cross-SG-GEN worker-PL-GEN active-ADESS-SG

organiseerimisel toimus öppus Valga

organizing-SG-ADESS take.place-PAST.3SG training-SG-NOM Valga-GEN

Punase Risti noortele

red-SG-GEN cross-SG-GEN young-PL-ALL

'Thanks to the active organizing by the Red Cross workers, there was a training session for the young members of Valga Red Cross'

(http://www.hot.ee/antiaids/pdf/project3.pdf)

\footnotetext{
Abbreviations: ABESS - abessive, ADESS - adessive, ALL - allative, COM - comitative, ELATelative, GEN - genitive, ILL - illative, PART - partitive, PST.PTCP - past participle, SUP - supine.
} 
I will refer to these expressions as adessive manner and cause (AMC) expressions. AMC expressions can be productively formed and are found at least since 1890, as is attested by the Tartu University "Corpus of Written Estonian 1890$1990 " 2$. The nouns heading the expressions are restricted to particular semantic classes (e.g. participating, organizing, instigating, encouraging, persuading, mediating, directing, wishing, demanding, allowing, reporting) but they do not form a closed class. The nouns are morphologically heterogeneous: they may be derived with any of the numerous action nominalization suffixes of Estonian (-mine, $-u s,-e,-u,-i,-n g,-k$ ) or through conversion; in addition, AMC expressions may occasionally be headed by borrowed nominalizations and by root nouns that occur in light verb constructions or from which there exist denominal verbs ${ }^{3}$. The AMC pattern has relatively high type-frequency, i.e. it occurs with a relatively large number of different lexemes. Many of these lexemes have very low token frequency in the AMC pattern, indicating that it is productive. Others however are very frequent in the $\mathrm{AMC}$ pattern, constituting fixed expressions.

AMC expressions are not regular noun phrases in that they are non-referential (i.e. the nouns do not take deictic or anaphoric determiners and cannot be referred to anaphorically, e.g. in a relative clause) and display fixed syntactic structure. Only the actor argument of the nominalization can be realized in the nominalization phrase, i.e. the nominalization cannot take any complements and the genitive NP cannot be object genitive - this despite the fact that the nominalizations that occur in these expressions all have more than one argument, and many of them can ordinarily take complements and/or combine with the object genitive. The expressions are also subject to an idiosyncratic constraint whereby the main clause or at least one of its constituents must be understood as a semantic argument of the nominalization: in example (1a), what the clients wish is the updating of Hanza.net, and in (1b), what is organized is the training session for the young members of Valga Red Cross.

In fact, these properties are not completely idiosyncratic: AMC expressions have similar meaning and function and complementary distribution with a handful of fixed transitive different-subject converb expressions, illustrated in ex. (3a) with a negative converb formed with the suffix -mata; the affirmative counterpart of the converb expression in (3a) is the AMC expression in (3b).

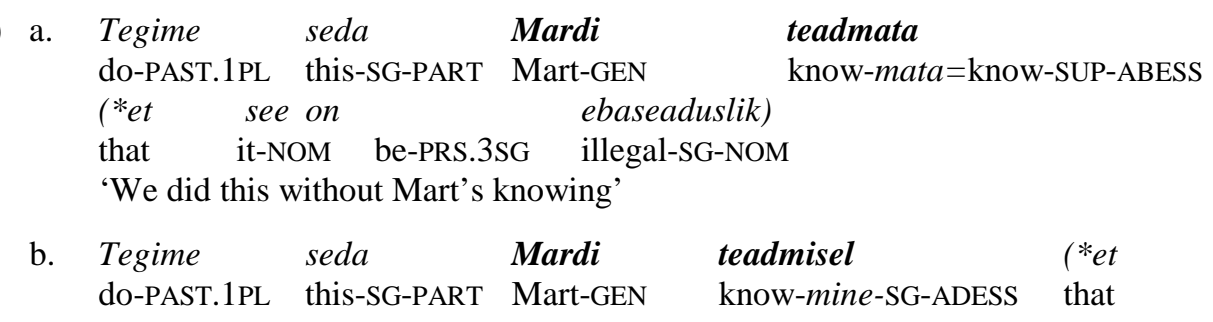

http://test.cl.ut.ee/korpused/baaskorpus/

3 For convenience, I will refer to the class of nouns heading AMC expressions uniformly as 'nominalizations', which is not completely accurate. 


$$
\begin{aligned}
& \text { see on ebaseaduslik). } \\
& \text { it-NOM be.PRS.3SG illegal-SG-NOM } \\
& \text { 'We did this with Mart's knowing' }
\end{aligned}
$$

The converb expressions are likewise two-member phrases, the converb combining with a genitive NP that realizes its actor argument; the converb clause cannot contain any other complements or adjuncts, and the main proposition is interpreted as the semantic argument of the converb (i.e. in example (3a), what Mart does not know is that we did it). Thus, the expressions are symmetrical with same-subject converb clauses headed by the same converbs: in these, it is the subject argument that is realized in the main clause and the object argument is realized in the converb clause.

A further characteristic that makes AMC expressions similar to converb expressions is their processual meaning, which is correlated with their nonreferentiality and the fact that the nominalizations in AMC expressions cannot be easily pluralized.

Another special property of AMC expressions, which makes them similar to the transitive different-subject converb expressions, is the obligatoriness of the subject genitive. This is not a conceptual or pragmatic necessity: in many cases an unrealized actor could be interpreted as impersonal or as coreferential with the subject of the clause.

As a further idiosyncratic characteristic AMC expressions display a combination of semantic and argument linking properties that in most cases cannot be reduced to the lexical properties of the nominalizations heading them. Namely, AMC expressions are characterized by processual meaning and subject genitive, whereas generally in Estonian nominalizations with processual meaning combine with the object genitive and nominalizations with non-processual meaning combine with the subject genitive (Kasik 1968:133). This can be illustrated with two nominalizations derived from the verb soosima 'to favour'. Soosing 'favour' is non-processual and combines with the subject genitive, whereas soosimine 'favouring' is processual and combines usually with the object genitive. In the AMC expressions, however, both nominalizations are interpreted as processual and combine with the subject genitive:

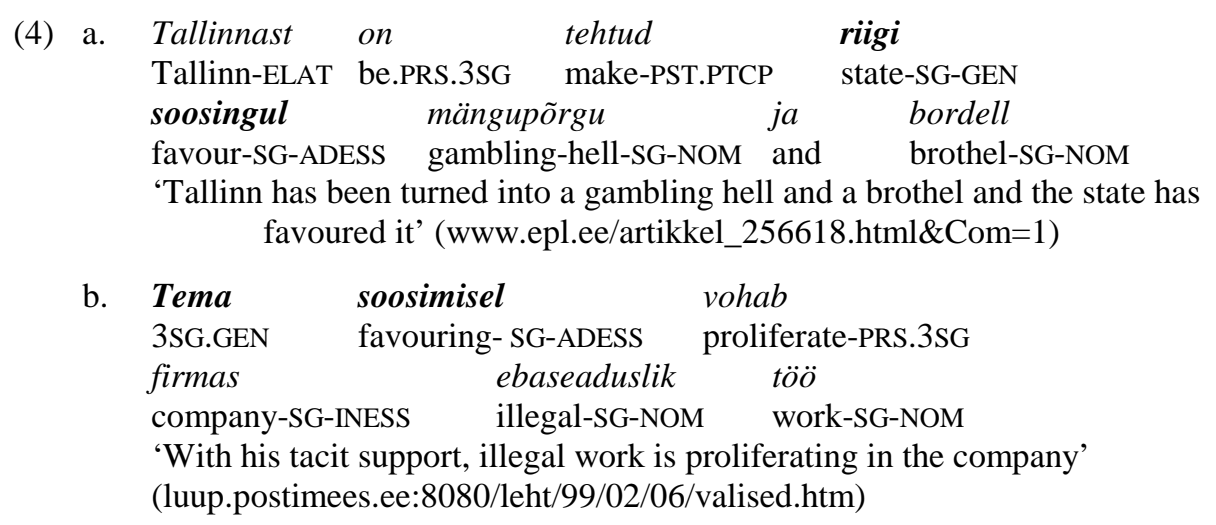


In some cases, it is not only the semantic type of the nominalization that changes in the AMC expression, but its lexical meaning more generally. For example, the nominalizations kirjastus, toimetus, and väljaanne, derived respectively from the verbs kirjastama 'to publish', toimetama 'to edit', and välja andma 'to publish', have the lexicalized meanings kirjastus 'publishing house', toimetus 'editorial board; editorial office' and väljaanne 'publication' (in the sense of a published work). However, in the AMC expressions they are synonymous with the corresponding processual mine-nominalizations kirjastamine 'publishing', toimetamine 'editing', and väljaandmine 'publishing', as in (5):

\section{(5) Raamat ilmus autori kirjastusel/kirjastamisel \\ book-SG-NOM appear-PAST.3SG author-SG-GEN kirjastus/kirjastamine-SG-ADESS \\ 'The book was published by the author'}

Thus it could be said that the meaning of the nominalizations in AMC expressions is determined by the corresponding verb, independently of the nominalizations' lexicalized meaning.

In conclusion, $\mathrm{AMC}$ expressions present a problem for a view of grammar that reduces the structure and meaning of complex expressions to the combinatorial and semantic properties of their component elements. Their syntactic structure, argument realization and coreference patterns, and semantic type or meaning are not predicted by the categorial, combinatorial and semantic properties of the nouns heading them. At the same time, they cannot be analyzed as a closed set of idiomatic expressions because they can be formed productively. Still, it has been proposed to account for the idiosyncratic syntax of AMC expressions in terms of ongoing changes in the categorial properties of individual noun forms. This account will be discussed in the next section.

\section{Grammaticalization analysis of AMC expressions}

The fixed structure of particular more entrenched AMC expressions has been noticed before, but the full extent and the productivity of the pattern, the predicateargument relationship between the adessive noun and the main proposition, and the parallel with converb expressions has not been described earlier. The expressions have not been subject to a separate study before, but their formulaic structure has repeatedly prompted the hypothesis that the forms appearing in the expressions are noun forms that have grammaticalized or are grammaticalizing into postpositions. This account is part of a well established tradition, common to both Estonian and Finnish linguistics, to account for fixed and non-referential uses of case forms as resulting from their ongoing development into adpositions ${ }^{4}$. With the advent of grammaticalization theory this account was cast in terms of

4 There exists a parallel explanatory framework, in terms of adverbialization, for fixed unmodified uses of case forms. 
grammaticalization (e.g. Habicht 2000, Haukioja 2000, Jaakola 1997, Ojutkangas 2001, who make reference to DeLancey 1997, Heine et al. 1991 and Lehmann 1985), but the explanatory framework was in place before that (cf. Karelson 1972, Penttilä 1957:337-343, Sadeniemi 1960). The framework is based on the fact that most Finnic adpositions can be traced back to noun forms (Grünthal 2003, Laanest 1975:192). It is part of a more general paradigm of explaining synchronic phenomena in terms of grammaticalization (cf. e.g. Habicht 2000:20; Heine 2002; Hopper and Traugott 2003:1-2; Jaakola 1997:121; Lehmann 1985; Metslang 2002:165-6, 2006:177-8,188; Trousdale and Traugott 2008); in fact, the large majority of Estonian grammaticalization studies listed in the overview of Helle Metslang (2002:173-4) are characterized by her as "the study of the means of Estonian language in a synchronic perspective".

In this framework, the occurrence of noun forms in fixed distributional patterns is described as resulting from their ongoing grammaticalization into postpositions, a development which gives rise to a synchronic continuum between nouns and adpositions (Jaakola 1997:126, Ojutkangas 2001:46-47). The process is described as being driven by the analogy of existing adpositions (Habicht 2000:22, Ojutkangas 2001:63) or by an analogical pattern permitting to create new adpositional constructions (Jaakola 1997:128). It applies to relational nouns (Jaakola 1997: 126-7) in particular contexts (Jaakola 1997: 128,156, 2008; Ojutkangas 2001:63), and involves a semantic change towards a more abstract meaning (Jaakola 1997: 128, Ojutkangas 2001:59sqq.). Adpositions are thus characterized as an open and gradient category, which constantly acquires new members through a gradual process of semantic change and decategorialization of noun forms (or verb forms) (cf. Grünthal 2003:56; Habicht 2000:22; Jaakola 1997, 2008; Metslang 1994:13; Hakulinen 2004:674-5; Erelt et al. 1995:38; Ojutkangas 2001).

This framework has been applied to single forms appearing in AMC expressions in two ways. First of all, it has been used in order to explain or to describe their fixed syntactic behaviour. The "Concise Morphological Dictionary of Estonian" (Viks 1992) and the "Defining Dictionary of Standard Estonian" (EKSS) characterize a series of nouns appearing in AMC expressions as adpositions (e.g. abil 'help-adess', tõukel 'push-adess', toel 'support-adess', sunnil 'forcing-adess' in Viks 1992) or as "close to adpositions" (e.g. abil 'help-adess', toimetusel 'editing-adess', toel 'support-adess' in EKSS). K. Kerge (2002:3) notes that certain mine-nominalizations in specific case forms seem to be developing into adpositions. Sepper (2006:50sqq.) analyzes one group of nouns occurring in the AMC pattern as grammaticalizing into evidential adpositions (e.g. väitel 'claim-adess', sõnul 'word-adess-pl', ütlusel 'saying-adess', teatel 'communication-adess'). Secondly, AMC nouns and the related expressions in Finnish have been cited as examples of the ongoing grammaticalization of noun forms into adpositions (Metslang 2002:165,174; Jaakola 1997:128,151, 2008).

However, the grammaticalization account of the exceptional properties of AMC expressions is undermined by the productivity of the pattern, i.e. it is not the case that individual noun forms are gradually acquiring the exceptional properties. 
Instead, they acquire these properties en bloc through their occurrence in a productive pattern, so that the forms that can exhibit these properties do not form a closed class. ${ }^{5}$ Furthermore, even those nominalizations that are the most entrenched in this pattern have not become more postposition-like. They continue to combine with modifying adjectives, i.e. the structure of the expressions has not become more postposition phrase-like, and the meaning of the nominalizations has not become more abstract as would be expected if they were developing into postpositions: they have maintained the meaning and the semantic argument structure determined by the corresponding verb. ${ }^{6}$ That the AMC use of nominalizations is not an intermediate step inevitably leading to their development into postpositions, is further confirmed by the fact that the nominalizations found in the pattern may be semantically quite specific and thus unlikely to develop the kinds of meanings expressed by adpositions, e.g. kaasfinantseerimisel 'with the cofinancing of', kureerimisel 'under the curatorship of' etc. In short, the exceptional configuration of properties characterizing AMC expressions is stable and productive, and thus cannot be explained with the gradual change of individual noun forms.

Some of this counterevidence is recognized in earlier treatments of AMC expressions as well, but the grammaticalization framework seems to be so firmly established as to impose itself independently of the evidence, as it were. For example, Sepper (2006:50) notes the semantic relationship with the base verb and the productivity of the pattern. Kerge (2002:53) notes that the fact that certain mine-nominalizations in specific case forms seem to be developing into adpositions, does not necessarily imply that they will lose the semantic relationship with the paradigm of the corresponding nominalization and its base verb, although grammaticalization is precisely assumed to involve semantic change and detachment from the paradigm (Jaakola 1997:128,156).

In conclusion, the exceptional properties of AMC expressions cannot be derived from the exceptional properties of a closed class of noun forms (or a morphological marker) undergoing a process of grammaticalization. The next section will propose a constructional account of AMC expressions.

5 An alternative grammaticalization analysis, which would account for the productivity of the pattern, would be to say that it is not the individual noun forms that are grammaticalizing but a common morphological or phonetic sequence shared by all the expressions. However, as was said above, the nominalizations appearing in AMC expressions are morphologically heterogeneous. Consequently, they possess no common material that could be undergoing a reanalysis.

6 Still, there is at least one instance in which the meaning of the noun in the AMC expression is more abstract than the meaning of the corresponding verb (and of the corresponding noun), namely the form abil 'with the help of' or simply 'with'. It can take an adjectival modifier if its meaning corresponds more literally to that of the verb but not in the more abstract uses. 


\section{Constructional analysis of AMC expressions}

Being simultaneously idiosyncratic and productively formed, AMC expressions represent one of the types of phenomena that have inspired the creation of construction-based models of grammar (cf. e.g. Goldberg 1995, Kay and Fillmore 1999, Croft 2001, Fried and Östman 2004): expressions with idiosyncratic formal properties and/or idiomatic meaning which however are productively formed and partially regular. The constructional approach has grown out of the observation that "the realm of idiomaticity in a language includes a great deal that is productive, highly structured, and worthy of serious grammatical investigation" (Fillmore, Kay, O'Connor 1988:534). Therefore,

a large part of a language user's competence is to be described as a repertory of clusters of information including, simultaneously, morphosyntactic patterns, semantic interpretation principles to which these are dedicated, and, in many cases, specific pragmatic functions in whose service they exist (ibid.).

In a constructional model, the structure and meaning of complex expressions may thus be licensed by meaningful morphosyntactic patterns that are of highly varying generality and schematicity and that are represented independently of the lexical items that enter them. Consequently, the structure of an expression does not have to be reduced exclusively to the categorial and combinatorial properties of its head, and its meaning does not have to derive compositionally from the meanings of its component elements. And conversely, the meaning and distribution of a lexical item may be determined not only by its inherent properties and general grammatical rules or constraints, but also by more or less idiomatic and idiosyncratic patterns with which it combines. These patterns form a continuum with the most general grammatical constraints on the one hand, and the individual words on the other hand. All these units of linguistic knowledge are represented in the same format, as complexes of formal, semantic, and pragmatic constraints, termed 'constructions'. Constructions constitute a single network of symbolic units related by multiple inheritance links and combining or unifying with each other to yield the actual expressions or 'constructs'. Upon encountering a class of expressions with noncompositional meaning and/or idiosyncratic formal properties, the constructional approach permits to recognize and to represent in detail the idiosyncratic properties by positing a separate construction licensing these expressions. At the same time, it permits to sort out all the properties that are shared by other classes of expressions and to represent the resulting generalizations by means of multiple inheritance links between constructions of different specificity (cf. Fillmore 1998). In other words, the constructional model provides theoretical mechanisms for representing both the idiosyncracies and different levels of generalization.

Consequently, the exceptional formal properties and the partly non-compositional meaning of AMC expressions can be represented as being licensed by a partially schematic and productive complex construction which constitutes an independent unit of linguistic knowledge. The AMC construction would consist of a complex of constraints determining the following properties of the expressions it 
licenses: their constituent structure, the adessive case form of the nominalizations, the adverbial meaning and function and the semantic type (process) of the expressions, the semantic classes of nominalizations that can enter them, the predicate-argument relationship between the nominalization and the main proposition, and the linking of the actor argument of the nominalization to the genitive NP. Mismatches between the lexical properties of nominalizations and their properties in AMC expressions would be explained as coercion effects (cf. e.g. Michaelis 2004:24-30) produced by the AMC construction: it changes the semantic type or even the lexical meaning of a non-processual nominalization, and requires for a processual mine-nominalization to combine with a subject genitive. Similarly, the adverbial meanings of AMC expressions would be attributed to the construction rather than to the adessive marker alone, as the adverbial meanings of expressions containing an adverbial case marker usually are: in order for a noun to function as an AMC adverbial, it must satisfy more constraints than that of being in adessive case.

Occurrence of adjectival modifiers in AMC expressions, on the other hand, does not seem to be specified by the AMC construction itself. This is suggested by the fact that the combination of nominalizations with adjectives is not completely free in AMC expressions: noun-adjective combinations occurring in the expressions are often fixed collocations, and adjectival modifiers occur only with those nominalizations whose meaning in the AMC expression is compatible with their lexical meaning, i.e. that designate either a processual or non-processual activity. Nominalizations that have lexicalized in some other meaning, as for example the nouns kirjastus 'publishing house', toimetus 'editorial board; editorial office' and väljaanne 'publication' discussed in section 2, do not take adjectival modifiers in their AMC use. AMC expressions that contain adjectives can thus be seen as licensed by the combination of the AMC construction and the modifying adjective construction. Hence, while the AMC construction overrides certain lexical properties of the nominalizations with which it combines, as for example their ability to combine with the object genitive, it does not completely override their ability to combine with the modifying adjective construction.

The constructional framework thus permits to represent not only the idiosyncratic properties of AMC expressions, but also the properties they share with other expression types. Another way of representing similarities in the constructional framework is in terms of constructional inheritance. Inheritance permits to represent the similarities between AMC expressions and transitive different-subject converb expressions. In a constructional account, these similarities do not have to be represented on the level of the lexical descriptions of nominalizations and converbs. Instead, they may in principle be formulated directly as a generalization over complex constructions, i.e. without deriving the similarities between complex expressions from identical lexical properties of their heads. In order to represent a generalization over the AMC construction and the converb construction, their common properties can be formulated as a more general construction which they both inherit. Moreover, such an inheritance relationship would motivate most of 
the exceptional properties of AMC expressions: their non-referentiality, processual meaning, linking properties, constituent structure. ${ }^{7}$ In other words, in the constructional account the idiosyncratic properties of AMC expressions would not be completely arbitrary (although they would be conventional) but would be motivated by their meaning as well as by other constructions in the grammar.

Since the constructional framework permits different levels of generalization, it makes it possible to represent not only the general AMC construction, but also its entrenched combinations with particular nominalizations. This can be done by positing these combinations as partially lexically filled sub-constructions of the more schematic AMC construction. These sub-constructions in turn may give rise to completely substantial sub-constructions which specify lexically both the nominalization and the subject genitive, e.g. oma $(l)^{8}$ soovil 'of one's own volition'.

In conclusion, AMC expressions receive a natural account in the constructional framework - it is precisely of such 'formal idioms' (Fillmore, Kay, O'Connor 1988:505-506) as the AMC construction that a large part of linguistic knowledge is assumed to consist. The construction-level approach enables to account for those aspects of AMC expressions that pose problems for synchronic or diachronic accounts in terms of the lexical properties of the nominalizations: the mismatch between the properties of the expressions and the properties of the head, as well as the simultaneous idiosyncracy, context-specificity, partial productivity and stability of the exceptional properties. The constructional approach also permits to represent the different levels of entrenchment of the various instances of the construction, the similarities between AMC expressions and converb expressions, and the fact that the construction is motivated by other constructions in the grammar.

In conclusion, the grammaticalization approach and the constructional approach suggest different analyses of the expressions under examination. Next, it will be argued that the reason for this divergence lies in the fact that the two analyses presuppose different conceptions of grammar.

\section{The grammaticalization analysis as an artefact of a synchronic conception of grammar}

In section 3 it was concluded that the grammaticalization analysis of AMC expressions is driven by the existence of a firmly established explanatory framework based on analogy with diachronic evidence, i.e. the fact that most postpositions can be traced back to noun forms. However, the counterarguments to the grammaticalization analysis suggest that the framework is being applied to a broader range of phenomena than is warranted by evidence. From the construc-

7 In the full representation of the inheritance relationships motivating the AMC construction it would also have to be linked to a family of adessive adverbial constructions, many of which are likewise idiomatic and partially productive.

8 The reflexive possessive pronoun oma may agree with the noun it modifies. 
tional perspective it appears that the reason for this may lie in the lack of descriptive and theoretical means for describing the whole range of the distribution of noun forms. Consequently, the reason why AMC expressions have been given a diachronic account lies in the assumed synchronic model of grammar rather than in actual diachronic evidence or in exact analogy with attested historical facts. This means that the grammaticalization hypothesis presupposes a particular set of legitimate categories and structures - since AMC expressions do not fit into the posited categories, they are hypothesized to be undergoing a transition from one posited category to another. In other words, the grammaticalization hypothesis of AMC expressions appears as an auxiliary mechanism that permits to maintain the posited categories and structures in the face of anomalous data, by locating these on the diachronic axis. On the constructional view, on the other hand, grammar is constituted in large part by idiomatic and idiosyncratic patterns. Therefore, phenomena that do not derive from previously posited constructions are not automatically assumed to fall outside the grammatical system but can be given a synchronic account by positing constructions that license them. For the same reason, the constructional approach, unlike the grammaticalization approach, allows to notice the productivity of the idiosyncratic AMC pattern. Consequently, from the constructional perspective there is no reason to analyze AMC expressions as resulting from ongoing change.

More particularly, what are hypothesized to be grammaticalizing are the nouns heading the expressions. Consequently, the grammaticalization hypothesis presupposes a conception of grammar in which the properties of a complex expression derive from the properties of its component elements, in particular the head. Therefore, the exceptional properties of the expressions are reduced to the exceptional lexical descriptions of their heads. On the constructional approach, on the other hand, complex expressions may be licensed by (combinations of) complex constructions. Therefore, the exceptional properties of AMC expressions are not assumed to necessarily reflect the lexical properties of the head but may be imposed by an independent construction. In other words, from the constructional perspective, the lexical description of a noun does not have to vary according to whether it appears in a productively formed AMC expression or in a regular NP.

The lexical property that is more particularly hypothesized to be changing in the course of the grammaticalization of the noun forms, is their category. Consequently, the main determinant of the distribution of a lexical item is assumed to be its category. The constructional approach, on the other hand, as has been demonstrated by Croft (2001), permits to treat the distributional contexts of a lexical item, i.e. the constructions in which it occurs, as the primitive units of grammar. In other words, it allows for a perspective in which it is not the categories that determine the distribution, but the distributional patterns that determine the categories. Croft (2001) shows that the way distributional method is used in order to establish the categories assumed to be the primitive units of syntactic representation, is circular: 
Constructions are used to define categories - this is the distributional method. But then the categories are taken as primitive elements of syntactic representation and are used to define constructions - this is the syntactic model of representation (Croft 2001:45).

From this perspective, the same circularity can be seen to carry over to the definition of exceptional distribution in terms of partial, graded or changing category-membership: "adding gradience is just a patch required for a flawed model of grammatical categories" (Croft 2007:418). Thus, from the constructional perspective it is the AMC construction that determines the category of lexical items that occur in it, not the other way around.

In conclusion, the comparison of the grammaticalization and constructional analyses of AMC expressions reveals that the grammaticalization hypothesis is informed by a synchronic conception of grammar which posits a particular set of legitimate structures determined primarily by the inherent combinatorial properties of lexical items (in interaction with general rules or constraints). The constructional approach, on the contrary, has grown out of the recognition that "in the construction of a grammar, more is needed than a system of general grammatical rules and a lexicon of fixed words and phrases" (Fillmore, Kay, O'Connor 1988:534). The solution of the constructional approach is therefore to posit a different conception of grammatical units and mechanisms, which allows a wider range of legitimate structures. It thus predicts that a more detailed exploration of the phenomena subsumed under the noun-postposition continuum would lead to the discovery of a series of lexically specific or partially productive patterns which may nevertheless constitute stable units of linguistic knowledge.

\subsection{The conception of grammar underlying the theory of grammaticalization}

Grammaticalization studies are often not based on an explicit conception of grammar, although the importance of the underlying model of grammar has been recognized:

In thinking about a theory of grammaticalization it is essential to have a clear concept of "grammar" in mind, for the most crucial point about grammaticalization is that it is a process whereby units are recruited "into grammar" (Traugott 2003:626).

Still, the same (implicit) assumptions about grammar that are revealed by the grammaticalization hypothesis of AMC expressions can be seen to inform certain aspects of the conception of grammaticalization more generally, especially as it is applied to synchronic data. At the same time, these assumptions seem to be in conflict with the findings of grammaticalization studies, which has led to certain inconsistencies in the theory of grammaticalization, especially regarding the status of complex structures.

One indication of the underlying conception of grammar is the assumption that grammaticalization primarily affects individual lexical elements (e.g. Hopper and Traugott 2003:2, Heine and Kuteva 2002:2) and consists in the change of their category-membership (e.g. Hopper and Traugott 103 sqq., Heine and Kuteva 
2002:9). This assumption presupposes a conception of grammar, the principal mechanism of which are the inherent combinatorial and categorial properties of lexical items. In other words, the distribution of each element is assumed to reflect its own inherent requirements, and complex structures are assumed to be epiphenomenal reflections of the inherent properties of their component elements (constrained by general rules or principles) ${ }^{9}$. Another reason why grammaticalization tends to be associated with individual lexical elements seems to lie in the fact that grammaticalization is described as being triggered by change in meaning, and only lexical items are assumed to be conventionally associated with meaning ${ }^{10}$. This view presupposes a conception of grammar in which combinatorial patterns or rules are purely formal, and the meaning of complex expressions derives compositionally from the meanings of their component elements.

However, the assumption that grammaticalization is located primarily in individual lexical elements, is in conflict with the findings of grammaticalization studies. It is recognized that in fact larger units can grammaticalize, although this is seen as a problem:
A number of developments leading to the evolution of grammatical categories do not involve linguistic units like words or morphemes; rather, they concern more complex conceptual entities, such as phrases, whole propositions, or even larger constructions. ... A related problem concerns what one may call "complex grammaticalization": a more complex linguistic structure can assume a grammatical function without involving the grammaticalization of any particular item figuring in this structure (Heine and Kuteva 2002:6-7).

Even if the process of grammaticalization can be located in a particular word or morpheme, it is often described as occurring in a particular context:

Since the development of grammatical forms is not independent of the constructions to which they belong, the study of grammaticalization is also concerned with constructions and with even larger discourse segments (Heine and Kuteva 2002:2; cf. also Traugott 2003).

It is thus recognized that the grammaticalizing form may be part of a larger structure, which consequently must be represented as a whole. That complex patterns are attributed certain representational independence is further suggested by the fact that grammaticalization theory has been found to be compatible with Construction Grammar, and that the notion of construction has been used in the sense of the context of grammaticalization (e.g. Diewald 2006, Traugott 2003; see also the overview in Noël 2007). Another concept that locates grammaticalization in a complex structure is that of reanalysis (e.g. Hopper and Traugott 2003:40 sqq.). In short, grammaticalization is often described, in one way or another, as

9 E.g. Heine (2003:595) treats changes in syntactic structure as epiphenomenal products of changes involving particular items.

10 This is made clear e.g. by this quotation from Heine (2003:581): "there are no convincing examples so far to suggest that instances of grammaticalization processes can be identified exclusively in terms of constructions without referring to the form-meaning items involved in the process." 
occurring in a complex structure, but it is nearly always recast as located fundamentally in individual words and morphemes. The reason for this change of perspective can be seen to lie in the assumed model of grammar which forces to reduce all syntagmatic phenomena to their component elements. This has led to an inconsistent treatment of the status of complex structures in the studies of grammaticalization: the units that undergo grammaticalization are treated in the spirit of a 'words and rules'-type of approach, in which complex structures do not have independent representational status and can thus change only epiphenomenally, as a result of changes taking place in words and morphemes, whereas the contexts in which these units occur are treated in the spirit of the constructional model, in which complex structures may be represented as wholes. ${ }^{11}$

Another aspect of the conception of grammaticalization that points to the assumed model of grammar is the teleological nature of its synchronic implementations, indicated by use of notions like 'ongoing' or 'incomplete' grammaticalization and by the fact that exceptionality tends to be taken as evidence of change, as in the grammaticalization analysis of AMC expressions. Some phenomena are thus treated in their own terms whereas some are treated in terms of other phenomena, as moving towards or away from these. This suggests that grammar is assumed to consist in a particular fixed inventory of categories and structures towards which the processes of grammaticalization are expected to tend. The conflict between this assumption and the findings of grammaticalization studies is manifested in the recognition that grammaticalization does not necessarily reach the predicted end-point:

...the particular course of events in any cline that is presented is not predetermined, once the "slippery slope" is embarked upon, continued grammaticalization is not inevitable, but may be suspended indefinitely at any point (Hopper and Traugott 2003:106).

The use of notions like graded or more or less prototypical category-membership (e.g. DeLancey 1997, Hopper and Traugott 2003:106, Traugott and Trousdale 2008) indicates that it is recognized that exceptional phenomena may be stable and have to be described as being part of grammar, i.e. that they are not simply extragrammatical transitional stages between regular units of language. ${ }^{12}$

11 A somewhat similar conflict has been pointed out by Janda (2001:284, note 4) with respect to the morpheme-centred view of grammaticalization: "Virtually all discussions of grammaticalization characterize that phenomenon in terms referring to the diachronic development of individual morphemes. But the synchronic work carried out by one of the major grammaticalizationists, Joan Bybee, is noted for advocating an associationist/connectionist model of the lexicon which downplays individual morphemes." Janda sees a promise in the approach of Traugott (2003) which makes use of the notion of construction; however, in this paper the term "construction" is still primarily used in the sense of the context of grammaticalization, not in the sense of the units that grammaticalize.

12 Another reaction to the finding that linguistic phenomena do not fit into the posited categories has been to propose that there is no fixed grammatical system at all (e.g. Hopper 1987, Hopper and Traugott 2003:17). The constructional approach is an alternative reaction: it proposes an alternative model of grammar which allows for a wider range of legitimate structures. 
In conclusion, it can be said that the conception of grammaticalization is partly dependent on the assumed conception of grammar: what are expected to be the units that enter into and result from the processes of change depends on what are assumed to be the units and mechanisms of grammar. At present, many grammaticalization studies seem to assume a conception of grammar in which linguistic structures result from an interaction between the inherent properties of lexical items and general formal rules or constraints. The next section will consider some examples of how grammaticalization and linguistic change more generally could be conceived of in terms of a construction-based model of grammar. The constructional model can be seen to conform well with the findings that appear problematic from the perspective of the model of grammar assumed in many grammaticalization studies at present: the constructional view is consistent with the syntagmatic and context-specific nature of grammaticalization, as well as with the finding that it does not necessarily reach the predicted end-point, and that idiosyncratic structures may be stable. Therefore, it is worth considering adopting it as the model of grammar underlying the study of grammaticalization.

\section{Constructions as units of change}

It was argued above that what are expected to be the units of change depends on what are assumed to be the units of linguistic knowledge. If complex constructions are assumed to be independently represented linguistic units, then they should also be susceptible to change as wholes. Noël (2007) gives an overview of the previous applications of the notion of construction in grammaticalization studies, and of diachronic studies conducted in the constructional framework. Proposals for basing grammaticalization studies on the constructional framework have been put forward e.g. by Leino (2003), Penjam (2006), Rostila (2006), Traugott (2003, 2007, 2008, ms.), Trousdale (2008), and in Bergs and Diewald (2008). This section will add to this line of thought by discussing certain diachronic developments that can be seen to involve the AMC construction posited in section 4, and by considering some implications of adopting the constructional model as the conception of grammar underlying the study of grammaticalization.

\subsection{Constructional reduction}

Although it was argued in section 3 that AMC expressions cannot be adequately analyzed as resulting from the ongoing grammaticalization of noun forms into postpositions, they can be seen to be subject to certain diachronic developments that can be described in terms of the AMC construction and its partly lexically filled sub-constructions. The first development can be related to the progressive conventionalization of the AMC construction and consists in the shortening of the construction.

As was mentioned above, Estonian possesses a number of action nominalization suffixes: one completely productive suffix (-mine) and a number of variously 
restricted suffixes (-us, $-e,-u,-i,-n g,-k,-n)$. Transitive nominalizations derived with the productive suffix -mine are the ones that usually have processual meaning and take the object genitive, whereas the others have non-processual meaning and take the subject genitive (see the discussion of ex. (4) in section 2).

As was said above, some AMC expressions have become entrenched in the language. In the older corpora, these expressions are often headed by the productive mine-nominalizations, whereas by now these have been replaced by shorter nominalizations formed with the less productive suffixes from the same verbs, e.g. ajamisel 'driving' > ajel 'drive, impulse', tahtmisel 'wanting, willing' > tahtel 'will', heakskiitmisel > heakskiidul 'approval', kaasaitamisel > kaasabil 'assistance', osavõtmisel 'participating' > osavõtul 'participation', nõusolemisel > nõusolekul 'consent', juuresolemisel > juuresolekul 'presence', eestkostmisel > eestkostel 'intercession'.

Concomitantly, the schematic pattern itself seems to have become more and more associated with shorter nominalizations, so that when a new instance of the pattern is productively formed, a shorter nominalization tends to be used (if available). This tendency can be illustrated with the results of a Google search (on 22.2.2007) of some such pairs, presented in Table 1.

Table 1. Occurrences of regular mine-nominalizations and shorter nouns corresponding to the same verbs in the AMC pattern

\begin{tabular}{|c|c|c|c|c|}
\hline Verb & $\begin{array}{c}\text { mine- } \\
\text { nominalization }\end{array}$ & $\begin{array}{c}\text { occurrences in } \\
\text { AMC phrase }\end{array}$ & $\begin{array}{c}\text { Shorter } \\
\text { nominalization }\end{array}$ & $\begin{array}{c}\text { occurrences in } \\
\text { AMC phrase }\end{array}$ \\
\hline $\begin{array}{l}\text { soosima } \\
\text { 'to favour' }\end{array}$ & $\begin{array}{l}\text { soosimisel } \\
\text { 'favouring' }\end{array}$ & 38 & $\begin{array}{l}\text { soosingul } \\
\text { 'favour' }\end{array}$ & 88 \\
\hline $\begin{array}{l}\text { ahvatlema } \\
\text { 'to tempt' }\end{array}$ & $\begin{array}{l}\text { ahvatlemisel } \\
\text { 'temptation' }\end{array}$ & 0 & $\begin{array}{l}\text { ahvatlusel } \\
\text { 'temptation' }\end{array}$ & 30 \\
\hline $\begin{array}{l}\text { julgestama } \\
\text { 'to guard' }\end{array}$ & $\begin{array}{l}\text { julgestamisel } \\
\text { 'guarding' }\end{array}$ & 2 & $\begin{array}{l}\text { julgestusel } \\
\text { 'guard' }\end{array}$ & 15 \\
\hline $\begin{array}{l}\text { inspireerima 'to } \\
\text { inspire' }\end{array}$ & $\begin{array}{l}\text { inspireerimisel } \\
\text { 'inspiration' }\end{array}$ & 0 & $\begin{array}{l}\text { inspiratsioonil } \\
\text { 'inspiration' }\end{array}$ & 11 \\
\hline $\begin{array}{l}\text { garanteerima } \\
\text { 'to warrant' }\end{array}$ & $\begin{array}{l}\text { garanteerimisel } \\
\text { 'warranting' }\end{array}$ & 1 & $\begin{array}{l}\text { garantiil } \\
\text { 'warranty' }\end{array}$ & 7 \\
\hline $\begin{array}{l}\text { manitsema 'to } \\
\text { admonish' }\end{array}$ & $\begin{array}{l}\text { manitsemisel } \\
\text { 'admonishing' }\end{array}$ & 0 & $\begin{array}{l}\text { manitsusel } \\
\text { 'admonition' }\end{array}$ & 8 \\
\hline
\end{tabular}

Thus it could be said that a kind of reduction has taken place, but it is not the reduction of a morpheme (it is not the suffix -mine or -misel that has become shorter), nor the reduction of a lexeme (it is not the lexeme ajamine that has either globally or locally reduced into aje): it is the shortening of the general AMC construction and its particular partly lexically filled sub-constructions, which 
could be caused by the conventionalization of the constructions. ${ }^{13}$ Another indication of the conventionalization of the construction is the increased coercion effect manifested in the change of the semantic type and possibly of the meaning of the shorter nominalizations.

In conclusion, in the case of AMC expressions, a process of reduction seems to have taken place that is related to progressive conventionalization. ${ }^{14}$ It is thus somewhat similar to the phenomenon of reduction described as part of the process of grammaticalization, with the difference that it cannot be described as the reduction of particular words or morphemes. This reduction through replacement would be therefore difficult to describe and to notice from the perspective of a word- and morpheme-centred conception of change. But a process of reduction can be represented as affecting a construction even if it can in principle be described in terms of a particular word, because words can be conceived of as parts of constructions. Similarly, the developing grammatical meaning that is seen as causing the reduction of a word can be attributed to the construction of which the word is a part, rather than to the reducing word alone.

An example of a case in which grammatical meaning has been attributed to complex constructions is the case of periphrasis (Ackermann and Webelhuth 1998, Booij (ms.), Blevins (ms.), Lee (2007)), which is also a much-studied example of grammaticalization. The treatment of periphrasis in grammaticalization studies can be seen as a manifestation of the conflict pointed out above: on the one hand, it is cited as the best known example of a case in which "grammaticalization involve[s] entire periphrastic constructions, or event schemata" and therefore cannot be described in terms of words and morphemes (Heine and Kuteva 2002:7); on the other hand, the development of verbs into auxiliaries tends to be described as an independent process, and the grammatical meaning associated with the periphrastic construction tends to be attributed to the auxiliary alone (Heine 1993). From the constructional perspective, the unit that acquires the grammatical meaning can be seen to be a complex construction involving a verb and a particular type of non-finite complement. Similarly, what appears from the lexical perspective as a change in the selectional properties of a word (the developing auxiliary which begins to combine with new semantic classes of non-finite complements and subject nouns), appears from the constructional perspective as a change in the selectional properties and an increase in the productivity of a complex construction.

13 Note that this replacement of one nominalization with another or their alternation in the AMC expression has no effect on the meaning and argument realization pattern of the expression as a whole, despite the fact that the different nominalizations are usually different in meaning or semantic type and have different linking properties - this is because the processual meaning and the linking pattern are conventionally associated with the construction, not determined by the lexical item.

14 In fact, the replacement of mine-nominalizations with shorter nominalizations in the course of conventionalization seems to be a more general phenomenon in Estonian. It can be observed in complex nouns, but also in complex predicate-like constructions involving nominalizations instead of non-finite verb forms. 
In conclusion, processes like reduction, progressive conventionalization, and semantic change together with the concomitant changes in selectional properties, whether they could in principle be described in terms of words and morphemes or not, can be conceived of in terms of constructions.

\subsection{Constructional 'lexicalization'}

The second diachronic development related to the AMC construction is the process whereby particular nominalizations become entrenched in the construction. This entrenchment is reflected e.g. in the special lexicographic treatment of some of the less regularly formed non-processual nominalizations that are frequently used in the AMC pattern (the regular mine-nominalizations are generally not included in the dictionary, and they probably strike the lexicographers as less odd in the AMC expressions since they maintain their lexical meaning, although not always their usual argument realization pattern). This can be illustrated with the treatment of the nominalizations kirjastus 'publishing house' (from the verb kirjastama 'to publish') and toimetus 'editorial board; editorial office' (from toimetama 'to edit'; cf. kirjastamine 'publishing', toimetamine 'editing') in the "Explanatory Dictionary of Written Estonian" (EKSS). In both cases the AMC use of the nouns (which is synonymous with the AMC use of the corresponding processual mine-nominalizations) is presented in a separate sense entry. In the case of kirjastus, this sense is defined with the respective processual mine-nominalization; toimetusel is presented directly in adessive case and described as 'postposition-like' (although it is paraphrased with the converb toimetatuna 'edited by').

The approach of the dictionary is a good illustration of the lexical approach: if an expression headed by a nominalization has processual meaning, then the nominalization must lexically possess processual meaning; and if a nominalization phrase does not behave as a regular NP, then the nominalization heading it must have lost its lexical categorial properties as a noun and shifted to another category, projecting a different type of phrase. In other words, the properties of the expression must reduce to the properties of the head. However, this description of the particular forms entrenched in the AMC pattern is problematic for the reasons pointed out above: on the one hand, the noun kirjastus cannot be said to be lexically associated with processual meaning, because it can appear in this meaning only in a single very specific morphosyntactic context; on the other hand, the special syntactic properties cannot be analyzed as resulting from the grammaticalization of individual noun forms into postpositions because they can be acquired productively by an open class of nouns.

From the constructional perspective, the nominalizations become entrenched in an idiosyncratic, partially productive construction. This process can be described as the rise of partly lexically filled sub-constructions of the schematic AMC construction, which would explain the local shift in the meaning of these nominalizations and their idiosyncratic syntax. That these entrenched combinations of the AMC construction with particular nominalizations remain related to 
the schematic construction is suggested by the fact that they seem to reinforce the productivity of the schematic construction by attracting semantically related words to it. This process of entrenchment can be seen as a kind of constructional counterpart of lexicalization: what emancipates from productive formation is not a new lexeme or a substantial idiom but a more specific sub-construction of a schematic construction. ${ }^{15}$

But the process whereby word forms become entrenched in the AMC construction may also be viewed as a process whereby new members join the category of words whose semantic and combinatorial properties match the AMC construction. However, this paradigmatic process can be seen as derivative with respect to the syntagmatic process of word-construction combination: it is the selection of a word form by the AMC construction that determines its membership in the category of words associated with the construction and its lexical semantic and combinatorial properties which match the construction. The heuristic value of a formal idiom like the AMC construction is that it permits to see that the category of words associated with it and the combinatorial properties of these words are determined by the construction, not the other way around; i.e. the construction is not an epiphenomenal reflection of the combinatorial properties of a particular category of lexical items. However, the same perspective can be applied to cases in which a lexical item occurs in a regular phrase type associated with a traditional word class. In other words, the combinatorial properties of lexical items can be conceived of as entrenched combinations of lexical items and constructions, or as partly lexically filled sub-constructions of independently represented schematic constructions (cf. Langacker 2000), and the categories of words can be seen to be defined by complex constructions with which the words combine (cf. Croft 2001:46-47).

In conclusion, what appears from the lexical perspective as the rise of a new lexical or grammatical element, or as a change in the distributional requirements of a lexical element, may alternatively be seen as the rise of a new sub-construction of a more schematic construction, or as a new word-construction combination.

\subsection{Constructional reanalysis and analogy}

AMC expressions suggest still another way how grammatical change could be described in terms of constructions. The reason why these expressions have been hypothesized to result from the grammaticalization of noun forms into postpositions is the formal and functional similarity of AMC expressions to postposition phrases: the latter too have two constituents, include an obligatory complement that is often in genitive, and may perform adverbial functions. It is therefore possible that a partly lexically filled AMC construction could become reanalyzed as an instantiation of the Postposition Phrase construction. In fact, as was mentioned in footnote 6 , there is at least one case in which a word form appearing

15 As was noted in section 4, the AMC construction has given rise to fully substantial subconstructions as well. 
in the AMC pattern is more postposition-like, namely abil 'with the help of' or 'with': it has an instrumental meaning that is more general than the meaning of the corresponding verb (whereas generally the meaning of an AMC expression is determined by the corresponding verb), and in these more abstract uses it does not seem to combine with adjectival modifiers. But abil has also more typical AMC uses, in which its meaning is more literally related to the meaning of the corresponding verb and in which it may combine with modifying adjectives. It is thus possible that the AMC sub-construction [NPgen + abil] has been reanalyzed as a sub-construction of the Postposition Phrase construction. Again, this process of 'constructional reanalysis' can be viewed from the lexical end as well, i.e. the form abil can be seen to have joined the category of words associated with the Postposition Phrase construction, but this time too the recategorization on the lexical level would be the result of a recategorization on the syntagmatic level.

This analysis differs from the kind of grammaticalization analysis discussed in section 3 in that the AMC use of abil is not seen as being outside the grammar as a mere transitory stage leading to its use as a postposition, nor is it construed as a kind of grammatical unit that is inherently programmed to change into something else, e.g. as a non-prototypical member of the category of postpositions programmed to change into a prototypical member. Instead, it is represented as being licensed by an independent construction that is a legitimate unit of grammar. ${ }^{16}$

If complex constructions are represented as wholes then it is also conceivable that they may undergo analogical changes as wholes, i.e. independently of the lexical representations of their component elements. For example, it could be hypothesized that the similarities between the AMC construction and the transitive different-subject converb constructions are the result of a process whereby a noun phrase construction licensing adverbial nominalization phrases has assimilated to the converb construction. Again, the constructional perspective would not entail a characterization whereby AMC expressions are an intermediate stage in a directional process having regular converb expressions as its goal - irregularity alone does not imply instability.

In conclusion, it is conceivable that complex constructions may undergo recategorization and analogical change as wholes, possibly giving rise to derivative effects on the lexical level. However, from the constructional perspective no structure appears as intermediate and instable merely because it is irregular, although certain factors (e.g. the type of meaning, formal and functional similarity or low frequency) may render the change more probable in some cases than in others.

16 It can of course still be said that abil fulfilled the necessary preconditions for this kind of reanalysis to take place, in that it had a meaning that was susceptible to generalize into the kind of meaning that is characteristic of adpositions. As was said in section 3, this is not true of all nominalizations appearing in the AMC pattern. 


\subsection{Implications of the construction-based approach for the conception of grammaticalization}

The previous sections attempted to point out some ways how grammaticalization and linguistic change more generally can be conceived of in terms of constructions. The present case study suggests two changes of perspective that a construction-based approach could entail in the conception of grammaticalization. Firstly, it would not give rise to the kind of teleological conception of grammatical change that invites to interpret idiosyncracy as evidence of change, because it takes linguistic knowledge to include a large number of idiosyncratic and partially productive patterns that are no less legitimate units of grammar than lexical items and general rules or constraints. The constructional model thus allows to represent idiosyncratic phenomena as being licensed by grammar. Therefore, it assumes no phenomena a priori to be inherently instable or extra-grammatical and does not predict what structures should result from change (this does not exclude predictions based for example on frequency or similarity, e.g. that similar structures may converge or that frequency or progressive conventionalization may cause reduction). Thus, from the constructional perspective, synchronic structures that have been analyzed as changing, or that have been organized as intermediate steps on a cline leading from one traditional category to another, may appear as licensed by stable constructions (as in the case of AMC expressions). And a change that has resulted in an idiosyncratic structure is not predicted to continue towards a regular end-point. As was noted in section 5.1, the teleological conception of grammaticalization is not in fact confirmed by the findings of grammaticalization studies: it is recognized that grammaticalization does not necessarily reach the predicted end-point. Consequently, the findings can be seen to accord better with the constructional model which allows for phenomena that are simultaneously idiosyncratic and stable, whether they result from a documented change or not.

The second change of perspective concerns the assumption that grammaticalization primarily affects individual words and morphemes. The previous sections attempted to show that it is possible to conceive of linguistic change in terms of complex constructions: constructions can arise as new units of linguistic knowledge (e.g. as more specific sub-constructions of a schematic construction), they can acquire a more 'grammatical' meaning (e.g. a combination of a verb with a particular type of non-finite complement can acquire an aspectual or temporal meaning, giving rise to a new periphrastic construction), they can become more productive (e.g. a verb-complement pattern that has acquired a grammatical meaning will start to combine with a larger number of verb classes), they can reduce in the course of progressive conventionalization (whether this process affects a particular lexical element that is part of the construction, or occurs on a more abstract level, e.g. in the form of replacement), they may become reanalyzed as sub-constructions of a different super-construction, and it is conceivable that they may undergo analogical changes (i.e. that complex constructions may grow more similar independently of the lexical representations of their heads). As was noted in sections 6.2 and 6.3, changes described in terms of constructions can 
often be viewed from a lexical perspective as well, because constructions contain words and morphemes as their parts. However, changes in the properties of a word (e.g. transition to another lexical category or acquisition of new combinatorial properties) can be seen as derivative with respect to processes on the syntagmatic level, just like the combinatorial and categorial properties of lexemes more generally can be seen to be inseparable from their combination with constructions. The constructional approach thus permits to describe both the constructional and the lexical side of linguistic change in an integrated manner.

As was noted in section 5.1, grammaticalization is in fact often described as a syntagmatic and context-specific phenomenon, i.e. as a process involving complex structures, but it tends to be defined in terms of individual words and morphemes. This has led to an inconsistent treatment of complex structures: they are not recognized as independent units of language that could undergo change (except when the change cannot be located in a single form), but they are attributed certain representational independence in the role of the context of change. The reason why complex constructions are not readily recognized as units of change can be seen in the underlying conception of grammar in which syntagmatic phenomena are assumed to be epiphenomenal. In the constructional approach, this obstacle to the treatment of complex structures as units of change is removed: complex constructions (whether schematic or completely or partially lexically filled) can be independently represented units of linguistic knowledge and thus can undergo change as wholes. Also, diachronic developments affecting complex constructions may be semantically triggered, just like the processes of grammaticalization currently described in terms of individual words and morphemes, because constructions are assumed to be conventionally associated with meaning. Moreover, Kay (1997) has shown that constructions may be conventionally associated with pragmatic information, which is described as another important trigger of grammatical change. Consequently, many questions related to the causes and mechanisms of change may remain the same on the constructional approach, although they may be viewed in terms of different kinds of units. The constructional approach would thus permit to solve the conflict in the treatment of complex structures and allow a more direct representation of the findings of grammaticalization studies: a process that is found to occur in a particular syntagmatic context does not have to be reduced to the change in the meaning and categorymembership of one particular element in this context. Words and morphemes would be seen as parts of larger units, which would explain the context-specific and syntagmatically conditioned nature of the processes of change that affect them.

But the constructional perspective also permits to notice and to account for a wider range of phenomena of change than the word- and morpheme-centred perspective, i.e. not only those phenomena that can be treated in terms of particular words and morphemes but also those that cannot, as for example the rise of new periphrastic constructions or a process of reduction which consists not in the shortening but in the replacement of a longer element with a shorter one in a 
particular context. Furthermore, the two types of phenomena would receive a uniform account in terms of constructions, i.e. the constructional approach would not be simply a complementary device applied only in cases in which a wordbased or morpheme-based account is impossible. Rather, it would entail constructional (re)formulations of phenomena that have been or could be cast in terms of words and morphemes. Since the process of grammaticalization of a particular element is often described as taking place in a specific context, such constructional reformulations would in many cases mean that what has been described as the context of change is recast as the unit that changes.

In conclusion, basing the study of grammaticalization explicitly on the constructional model of grammar could render the conception of grammaticalization more consistent both internally, as well as with the findings. Of course, the full implications and possible problems of adopting the constructional approach require an extensive study.

\section{Conclusions}

This paper was an attempt to demonstrate that the conception of grammaticalization is dependent on the assumed conception of grammar: the latter determines what are taken to be the units and mechanisms of linguistic knowledge and hence also what are expected to be the units that enter into and result from the processes of change. A comparison of grammaticalization and constructional analyses of a class of expressions revealed that the grammaticalization hypothesis presupposes a particular synchronic conception of grammar which can be seen to underlie the conception of grammaticalization more generally. This conception assumes the traditional word classes and phrase types as the legitimate categories and structures of grammar, as is indicated by the fact that phenomena that do not fit into these tend to be interpreted as transitional stages between regular structures. The assumption that grammaticalization primarily affects individual words and morphemes in turn indicates that only substantial lexical items are taken to be conventionally associated with meaning and that the meaning and form of complex expressions is assumed to reduce to semantic and combinatorial properties of lexical items.

However, the conception of grammaticalization informed by these assumptions can be seen to conflict with the findings of grammaticalization studies: these characterize grammaticalization as a syntagmatic and context-specific process that cannot always be described in terms of words and morphemes and that does not necessarily result in a regular structure. This conflict has resulted in an inconsistent treatment of exceptional phenomena: on the one hand, they are assumed to be intermediate stages between regular structures, on the other hand, it is recognized that they may be stable and that the assumed inventory of grammatical structures is insufficient (e.g. needs to be complemented by the conception of graded category-membership). Another manifestation of this conflict is the 
inconsistent treatment of complex structures: they are not readily recognized as independent units that can grammaticalize as wholes, whereas at the same time they are attributed the status of independent units in the role of the context of grammaticalization, as is evidenced among other things by the use of the notion of construction in this sense, and by the fact that grammaticalization theory has been found to be compatible with Construction Grammar, which implies a holistic conception of complex structures. However, since the conception of grammaticalization is dependent on a conception of grammar, the two can be compatible only if the constructional model is adopted as the conception of grammar underlying the conception of grammaticalization. Given the described inconsistencies regarding the status of complex structures and exceptional phenomena, the adoption of the constructional perspective on grammaticalization seems worth consideration. This would entail the revision of the teleological and word- and morpheme-centred aspects of the conception of grammaticalization. The constructional approach would predict that complex constructions may undergo change as wholes, thus accommodating the finding that grammaticalization cannot always be described in terms of words and morphemes and that the changes that do affect individual forms tend to be context-specific and syntagmatically induced. As a second change of perspective, the constructional approach would not predict what structures will result from change. As such, it can be seen to accord with the finding that grammaticalization does not always reach the predicted end-point and may result in structures that are simultaneously idiosyncratic and stable. But the constructional perspective would also entail reformulations of certain word- and morpheme-based grammaticalization analyses and would disclose new types of phenomena of change.

\section{Acknowledgements}

This study was financed by the base funding project "Meaning and usage of perceptual and action vocabulary" of the Institute of the Estonian Language.

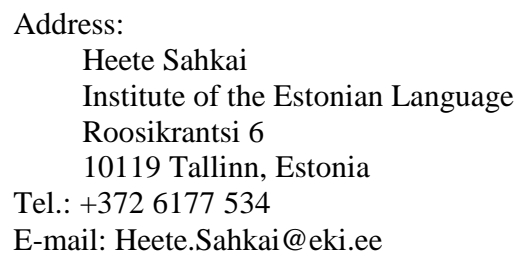

\section{References}

Ackerman, Farrell and Gert Webelhuth (1998) A theory of predicates. Stanford: CSLI Publications. Bergs, Alexander and Gabriele Diewald, eds. (2008) Constructions and language change. Berlin: Mouton de Gruyter. 
Blevins, James P. (ms.) "Periphrasis as syntactic exponence”. http://people.pwf.cam.ac.uk/jpb39/pdf/ drafts/synexp.pdf

Booij, Geert (ms.) "Constructional idioms and periphrasis: the progressive construction in Dutch". http://www.cs.engr.uky.edu/ gstump/periphrasispapers/Progressive.pdf

Croft, William (2001) Radical construction grammar. Oxford: Oxford University Press.

Croft, William (2007) "Beyond Aristotle and gradience: a reply to Aarts". Studies in Language 31, 2, 409-430.

De Lancey, Scott (1997) "Grammaticalization and the gradience of categories: relator nouns and postpositions in Tibetan and Burmese". In Essays on language function and language type. Dedicated to T. Givón, 51-69. Joan Bybee, John Hyman, and Sandra A. Thompson, eds. Amsterdam: Benjamins.

Diewald, Gabriele (2006) "Context types in grammaticalization as constructions". Constructions SV1-9/2006. urn:nbn:de:0009-4-6860 (http://www.constructions-online.de/).

EKSS = Eesti kirjakeele seletussõnaraamat. [The explanatory dictionary of written Estonian.] Tallinn, 1988-2007.

Erelt, Mati, Reet Kasik, Helle Metslang, Henno Rajandi, Kristiina Ross, Henn Saari, Kaja Tael, and Silvi Vare (1995) Eesti keele grammatika I. Morfoloogia, sõnamoodustus. [Estonian grammar I. Morphology, word formation.] Tallinn: Eesti Teaduste Akadeemia Eesti Keele Instituut.

Fillmore, Charles J. (1998) "Inversion and constructional inheritance". In Lexical and constructional aspects of linguistic explanation, 113-128. G. Webelhuth et al., eds. Stanford: CSLI Publications,

Fillmore, Charles J., Paul Kay, and Mary Catherine O'Connor (1988) "Regularity and idiomaticity in grammatical constructions". Language 64, 501-538.

Fried, Mirjam and Jan-Ola Östman (2004) "Construction grammar: a thumbnail sketch". In Construction grammar in a cross-language perspective, 11-86. Mirjam Fried and Jan-Ola Östman, eds. Amsterdam: John Benjamins.

Goldberg, Adele E. (1995) Constructions: a construction grammar approach to argument structure. Chicago: University of Chicago Press.

Grünthal, Riho (2003) Finnic adpositions and cases in change. (Suomalais-Ugrilaisen Seuran toimituksia, 244.) Helsinki.

Habicht, Külli (2000) "Grammaticalization of adpositions in old literary Estonian". In Estonian: Typological Studies IV, 19-58. Mati Erelt, ed. (Tartu Ülikooli eesti keele õppetooli toimetised, 14.) Tartu.

Hakulinen, Auli, ed. (2004) Iso suomen kielioppi. [The big grammar of Finnish.] Helsinki: Suomalaisen Kirjallisuuden Seura.

Haukioja, Timo (2000) “Adpositioista ja relationaalisista substantiiveista”. In Näkökulmia kielitypologiaan, 88-108. [On adpositions and relational nouns.] Anneli Pajunen, ed. (Suomi, 186.) Helsinki: Suomalaisen Kirjallisuuden Seura.

Heine, Bernd (1993) Auxiliaries: cognitive forces and grammaticalization. New York, Oxford: Oxford University Press.

Heine, Bernd (2002) "On the role of context in grammaticalization". In New reflections on grammaticalization, 83-102. Ilse Wischer and Gabriele Diewald, eds. Amsterdam: John Benjamins.

Heine, Bernd (2003) "Grammaticalization". In The Handbook of Historical Linguistics, 575-601. Brian Joseph and Richard D. Janda, eds. Oxford: Blackwell.

Heine, Bernd, Ulrike Claudi, and Friederike Hünnemeyer (1991) Grammaticalization: a conceptual framework. Chicago, London: University of Chicago Press.

Heine, Bernd and Tania Kuteva (2002) World lexicon of grammaticalization. Cambridge: Cambridge University Press.

Hopper, Paul (1987) "Emergent grammar". Berkeley Linguistics Society, 13, 139-157. http://home.eserver.org/hopper/emergence.html

Hopper, Paul J. and Elizabeth Closs Traugott (2003). Grammaticalization. Cambridge, New York: Cambridge University Press. 
Jaakola, Minna (1997) "Genetiivin kanssa esiintyvien adpositioiden kieliopillistumisesta". [The grammaticalization of the adpositions occurring with the genitive.] In Kieliopillistuminen. Tapaustutkimuksia suomesta,121-156. (Kieli, 12.) Tapani Lehtinen and Lea Laitinen, eds. Helsinki.

Jaakola, Minna (2008) "Where does the cline start? The relationship between nouns and adpositions in Finnish". Paper presented on 31 May 2008, Cognitive and Functional Perspectives on Dynamic Tendencies in Languages, Tartu, May 29 to June 1, 2008.

Janda, Richard D. (2001) "Beyond 'pathways' and 'unidirectionality': on the discontinuity of language transmission and the counterability of grammaticalization". Language Sciences 23: 265-340.

Karelson, Rudolf (1972) "Märkmeid kaassõna piirimailt". [Notes from the confines of adpositions.] Emakeele Seltsi aastaraamat (Tallinn) 18, 71-86.

Kasik, Reet (1968) "Omastavalise täiendi subjektilisusest ja objektilisusest mine-konstruktsioonis". [Subject and object genitives in the mine-construction.] Keel ja struktuur 2, 127-139. Tartu: Tartu Riiklik Ülikool.

Kay, Paul (1997) Words and the grammar of context. Stanford: CSLI Publications.

Kay, Paul and Charles J. Fillmore (1999) "Grammatical constructions and linguistic generalizations: The What's $X$ doing $Y$ ? construction". Language $75,1-33$

Kerge, Krista (2002) Aja- ja ilukirjandusteksti süntaktilise keerukuse dünaamika XX sajandil. [The dynamics of the complexity of the syntactic structure in the journalistic and literary texts of the 20th century.] TPÜ eesti keele osakonna veebitoimetised. Lingvistika 1. http://www.tlu.ee/fil/veebitoimetised/pdf/lingvistika1.pdf

Laanest, Arvo (1975) Sissejuhatus läänemeresoome keeltesse. [Introduction to Finnic languages.] Tallinn: Eesti NSV Teaduste Akadeemia Keele ja Kirjanduse Instituut.

Langacker, Ronald (2000) "A dynamic usage-based model". In Usage-based models of language, 1-63. Michael Barlow and Suzanne Kemmer, eds. Stanford: CSLI Publications.

Lee, Seung-Ah (2007) "Ing forms and the progressive puzzle: a construction-based approach to English progressives". Journal of Linguistics 43, 153-195.

Lehmann, Christian (1985) "Grammaticalization: synchronic variation and diachronic change". Lingua e Stile 20, 3, 303-318.

Leino, Jaakko (2003) Antaa sen muuttua. Suomen kielen permissiivirakenne ja sen kehitys. [Let it change. The Finnish permissive construction and its development.] Helsinki: Suomalaisen Kirjallisuuden Seura.

Metslang, Helle (1994) "Grammatikaliseerumisest eesti ja soome keeles". [On grammaticalization in Estonian and Finnish.] Lähivertailuja 7, 9-32. (Turun yliopiston suomalaisen ja yleisen kielitieteen laitoksen julkaisuja, 44.) Turku.

Metslang, Helle (2002) "Grammatikalisatsiooniteooriast eesti keele taustal". [The theory of grammaticalization from the persepctive of Estonian.] In Teoreetiline keeleteadus Eestis, 164-178. Renate Pajusalu, Ilona Tragel, Tiit Hennoste, and Haldur Õim, eds. (Tartu Ülikooli üldkeeleteaduse õppetooli toimetised, 4.) Tartu.

Metslang, Helle (2006). "Grammatisatsiooniteooriast tänase pilguga". [The theory of grammaticalization today.] In Teoreetiline keeleteadus Eestis II, 176-195. Ilona Tragel and Haldur Õim, eds. (Tartu Ülikooli üldkeeleteaduse õppetooli toimetised, 7.) Tartu.

Michaelis, Laura A. (2004) "Type shifting in construction grammar: an integrated approach to aspectual coercion". Cognitive Linguistics 15, 1, 1-67.

Noël, Dirk (2007) "Diachronic construction grammar and grammaticalization theory". Functions of Language 14, 2, 177-202.

Ojutkangas, Krista (2001) Ruumiinosannimien kieliopillistuminen suomessa ja virossa. [Grammaticalization of body part names in Finnish and Estonian.] Helsinki: Suomalaisen kirjallisuuden seura.

Penjam, Pille (2006) "Development of the modal function of the verb tulema 'come' in written Estonian”. Linguistica Uralica XLII 3, 167-191.

Penttilä, Aarni (1957) Suomen kielioppi. [Finnish grammar.] Porvoo, Helsinki: Werner Söderström Osakeyhtiö. 
Rostila, Jouni (2006) "Storage as a way to grammaticalization". Constructions 1, 2006. urn:nbn:de:0009-4-3458 (http://www.constructions-online.de/).

Sadeniemi, Matti (1960) "Post- ja prepositioista ja niiden rektiosta". [On postpositions and prepositions and their government.] Kielenkäytön kysymyksiä, 7-16. (Tietolipas, 18.) Helsinki: Suomalaisen kirjallisuuden seura.

Sahkai, Heete (2006) "Konstruktsioonipõhise keelekirjelduse võimalustest adessiivse viisi- ja põhjusmääruse näitel". [Adessive manner and cause adverbials and the advantages of a construction-based approach to language description.] Keel ja Kirjandus (Tallinn) 10, 816831.

Sepper, Maria-Maren (2006) Indirektaal eesti 19. sajandi lõpu ja 20. sajandi aja- ja ilukirjanduskeeles. [Indirect evidentiality in Estonian journalistic and fiction texts of the late 19th and the 20th centuries.] MA Thesis. Tallinn University.

Traugott, Elizabeth Closs (2003) "Constructions in grammaticalization". In The handbook of historical linguistics, 624-647. Brian Joseph and Richard D. Janda, eds., Oxford: Blackwell.

Traugott, Elizabeth Closs (2007) "The concepts of constructional mismatch and type shifting from the perspective of grammaticalization". Cognitive Linguistics 18, 4, 523-557.

Traugott, Elizabeth Closs (2008) "The grammaticalization of NP of NP patterns". In Constructions and language change, 23-45. Alexander Bergs and Gabriele Diewald, eds. Berlin: Mouton de Gruyter.

Traugott, Elizabeth Closs (ms.) Constructions, emergent constructions, and the notion of 'newness'. http://dialoguematters.stanford.edu/twiki-dm/bin/viewfile/Main/WorkshopThree?rev= 1.2; filename=TraugottEmergCxns.doc

Traugott, Elizabeth Closs and Graeme Trousdale (2008) "Gradience, gradualness and grammaticalization". Paper presented at NRG4, Leuven, 16-19 July 2008.

Trousdale, Graeme (2008) "Grammaticalization, constructions and the grammaticalization of constructions". Plenary lecture, NRG4, Leuven, 16-19 July 2008.

Viks, Ülle (1992) Väike vormisõnastik. [Concise morphological dictionary of Estonian.] Tallinn: Eesti Teaduste Akadeemia Keele ja Kirjanduse Instituut. 